\title{
Harmonisasi Hukum dalam Perspektif Perundang-Undangan
}

\author{
Kusinu Goesniadhie Slamet
}

\begin{abstract}
' Abstract
The special agency in accordance to Banking Law Number 10/1998 is an agency put forward to settle and to recover state funds formerly placed in the banking industries in time of severe economic crisis. The special agency has given a broad power to this agency even surpass the power or authority that normally become the power of the court. This regulation is one example of how sometimes Indonesian regulations are not in harmony to each others and become a stumble block in establishing due process of law, giving fair treatment and establishing good system of law. It is also no wonder if the effectiveness of this special regulation and the functions of the special agency it is created do not meet the requirement in settling government financial problem.

The purpose of this paper is to determine whether the existing regulations are in harmony each other, to analyze which regulation should put in place or which one should be remove, which theory or principle can be put forward or kept as the basic argumentation in creating hamonious law.

To be particular it is recommended that based upon consideration using normative anaIytical method on dogmatic legal system to create harmonious law in Indonesia, there must be a new law in banking namely, 'undang-undang penyelesaian bank bermasalah' which permanently become the guidance of any agency which its functions is to settle banking problem.
\end{abstract}

\section{Pendahuluan}

Esensi prinsip negara hukum dan prinsip pemerintahan berdasar sistem konstitusi yang ditegaskan dalam UUD 1945, menghendaki adanya suatu sistem hukum, yakni setiap norma hukum harus terkait dan tersusun dalam suatu sistem, artinya norma hukum yang satu tidak boleh mengesampingkan norma hukum yang lain. Sistem hukum nasional merupakan hasil proses harmonisasi antara sejumlah unsur dan faktor tertentu baik intern

domestik maupun ekstern internasional, yang diolah berdasarkan paradigma Pancasila dan UUD 1945.

Dalam kerangka sistem hukum nasional, semua peraturan perundang-undangan dipandang sebagai satu sistem yang utuh. Konsistensi dalam peraturan perundangundangan dapat disebut sebagai kepastian. hukum. Konsistensi dalam peraturan perundang-undangan itu bukan sesuatu yang 
terjadi dengan sendirinya melainkan harus diciptakan, sehingga dapat terjadi tidak konsisten dalam pembentukan peraturan perundang-undangan. Dari segi penegakan hukum konsistensi dalam tindakan dari lembaga kenegaraan sangat menentukan kadar kepastian hukum, dalam arti rapuhnya konsistensi dalam tindakan akan mengakibatkan kaburnya kepastian hukum. Kepastian hukum akan menjadi pengamatan masyarakat, karena masyarakat memiliki perasaan peka terhadap ketidakadilan.'

Sementara itu, ketentuan hukum dalam Pasal 37A UU No.10 Tahun 1998, tentang Perubahan Atas UU No.7 Tahun 1992, tentang Perbankan, yang menjadi dasar dibentuknya badan khusus ternyata terjadi tumpang tindih norma hukum. Badan khusus diberikan kedudukan istimewa dengan kewenangan besar, yaitu kewenangan menurut Pasal 37A UU No.10 Tahun 1998. Karakter yuridis kewenangan badan khusus, yaitu: (i) kewenangan khusus yang tidak dimiliki oleh institusi lainnya; (ii) merupakan lex specialis terhadap ketentuan peraturan perundangundangan lainnya; (iii) tindakan yang diambil oleh badan khusus dipersamakan dengan sebuah putusan pengadilan yang bersifat serta merta (uitvoerbaar bij voorraad); (iv) tindakan badan khusus adalah sah berdasarkan undang-undang; (v) permintaan badan khusus kepada bank dalam program penyehatan, merupakan perintah pejabat yang berwenang atau keputusan tata usaha negara yang harus dipatuhi.

Kewenangan dengan karakter khusus tersebut meliputi penggunaan wewenang yang ditentukan dalam Pasal 37A ayat (3) UU No.10 Tahun 1998, yaitu sejumlah wewenang khusus dari huruf a. sampai dengan huruf $m$., dan melakukan tindakan lain yang diperlukan untuk menunjang pelaksanaan wewenang, dalam huruf $n$. Dalam kewenangan dengan karakter khusus tersebut, norma hukum yang sama juga diatur di dalam peraturan perundang-undangan yang lain, sehingga saling tumpang tindih yang dapat dikatakan sebagai disharmoni peraturan perundangundangan. Pemberian kedudukan terhadap tindakan hukum yang dilakukan oleh badan khusus dipersamakan dengan sebuah putusan pengadilan yang bersifat uitvoerbaar bij voorraad, melanggar batas eksternal institusional kekuasaan badan peradilan umum di lingkungan. kekuasaan kehakiman khususnya peradilan perdata. Meskipun wewenang badan khusus merupakan lex specialis menurut ketentuan. Pasal 37A UU No.10 Tahun 1998, tetapi wewenang badań khusus dalam menjalankan fungsi penyehatan perbankan nasional tidak dapat mengingkari asas negara hukum dan asas demokrasi yang merupakan prinsip dasar ketatanegaraan dan konstitusi Indonesia.

Keadaan demikian diperlukan suatu sistem peraturan perundang-undangan yang harmonis, konsisten dan terintegrasi, yang dijiwai Pancasila dan bersumber pada UUD 1945, untuk mewujudkan ketertiban, menjamin kepastian dan perlindungan hukum. Hal ini berarti harmonisasi di antara peraturan perundang-undangan sangat diperlukan dan

' Budiono Kusumohamidjojo, Ketertiban Yang Adil, Problematik Filsafat Hukum (Jakarta: Grasindo, 1999), hlm.157. 
mendesak untuk ditakukan. Sehubungan hal itu harmonisasi hukum terhadap sistem peraturan perundang-undangan secara terintegrasi, muncul sebagai kebutuhan dan merupakan suatu keniscayaan. Harmonisasi hukum dalam peraturan perundangundangan sebagai subsistem hukum dalam kerangka sistem hukum nasional, sehingga norma-norma hukum dalam peraturan perundang-undangan tidak saling bertentangan dan tidak terjadi duplikasi atau tumpang tindih.

Urgensi dari harmonisasi hukum ini, di satu pihak memberikan landasan hukum yang kuat sesuai dengan hierarkhi peraturan perundang-undangan, di lain pihak dari segi sistem hukum dan asas hukum terwujud kesesuaian sistem hukum dan asas hukum, sehingga dalam penerapannya tidak terjadi konflik norma.

Masalah pokoknya ialah bagaimana kerangka pemikiran yang dapat digunakan dalam memahami konsep harmonisasi hukum untuk mengatasi terjadinya pertentangan-pertentangan, batasan perbedaan di antara ketentuan-ketentuan peraturan perundang-undangan sebagai sistem hukum dalam satu kesatuan sistem hukum nasional, sehingga tidak terhalang oleh pestentangan, perbedaan dan tidak terjadi tumpang tindih.

\section{Pemikiran Harmonisasi Hukum}

Rudolf Stammler mengemukakan konsep, prinsip-prinsip hukum yang adil mencakup harmonisasi antara maksud dan tujuan serta kepentingan perorangan, dan maksud dan tujuan serta kepentingan umum, ( $A$ just law aims at harmonizing individual purposes with that of society). ${ }^{2}$ Dengan kata lain, keadilan itu terjalin dengan kehidupan ekonomis masyarakat yang diwujudkan melalui hukum, maka hukum yang mewujudkan keadilan itu mutlak diperlukan di dalam kehidupan bermasyarakat. Menurut Radbruch, tugas utama hukum ialah mewujudkan keadilan, karena tiga kepentingan hidup bersama ialah tiga nilai dasar hukum, yaitu keadilan, kemanfaatan dan kepastian hukum. ${ }^{3}$ Menurut John Rawls, keadilan merupakan suatu nilai yang mewujudkan keseimbangan antara bagianbagian dalam kesatuan, antara tujuan-tujuan pribadi dan tujuan bersama. ${ }^{4}$ Berdasarkan pertimbangan dan persetujuan tentang prinsip-prinsip keadilan yang disebut "justice as fairness', dipandang cocok diaplikasikan pada negara berkembang termasuk Indonesia, karena menekankan perlunya ditegakkan dua asas yakni asas kebebasan dan persamaan warga negara serta asas perlindungan bagi kaum dhuafa yang keadaan ekonominya tidak menguntungkan dalam stratifikasi sosial, yang secara struktural tidak adil.

\footnotetext{
2Stammler, Definition of Law, dalam Hari Chand, Modem Jurisprudence (Kuala Lumpur: Intemational Law Book Services, 1994), hlm.49.

${ }^{3}$ Theo Huijbers, Filsafat Hukum dalam Lintasan Sejarah (Yogyakarta: Kanisius, 1982), hlm.288-289.

4 Johlmn Rawls, A Theory of Justice (London, Oxford, New York: Oxford University Press, 1973), him.100113.
} 
UNIDROIT, menciptakan cara untuk mengharmonisasikan dan mengkoordinásikan ketentuan-ketentuan hukum perdata dari negara-negara anggotanya dan mempromosikan penerimaan sistem hukum perdata yang 'uniform'.5 Masyarakat Batubara dan Baja Eropa melalui Perjanjian Paris 1951 (Verdrag van Parijs tot Oprichting van Europese Gemeenschap voor Kolen en Staal) dan Masyarakat Energi dan Atom Eropa melalui Perjanjian Roma 1957 (Europese Gemeenschap van Atoomenergie), serta Masyarakat Ekonomi Eropa (European Economic Community), secara bersama merupakan kesatuan European Community dalam usaha integrasi ekonomi yang diwujudkan terutama melalui usaha harmonisasi hukum di antara negara-negara anggota. ${ }^{6}$

Clive M. Schmitthoff, merumuskan harmonisasi hukum perdagangan internasional dalam UNCITRAL, mengembangkan dan meningkatkan harmonisasi progresif dalam bidang hukum perdagangan internasional. ${ }^{7}$ Mempresentasikan harmonisasi hukum banyak negara dengan berbagai macam tradisi hukum dan kultur hukum, berkerabat dengan karakter hukum transnasional. Semangat untuk melakukan harmonisasi dan unifikasi hukum perdagangan internasional melahirkan konsep "Lex Mercatoria", yaitu "common principles in the law relating to international commercial transactions", yang dapat ditemukan dalam "international legislation" dan "international commercial custom" antara lain dalam ICC, UNCITRAL, UNCTAD, dan ICSID. ${ }^{8}$

Badan Pembinaan Hukum Nasional Departemen Kehakiman, memberikan pengertian harmonisasi hukum sebagai kegiatan ilmiah untuk menuju proses pengharmonisan hukum tertulis yang mengacu baik pada nilai-nilai filosofis, sosiologis, ekonomis maupun yuridis. Pengkajian terhadap rancangan peraturan perundang-undangan, dalam berbagai aspek apakah telah mencerminkan keselarasan dan kesesuaian dengan peraturan perundangundangan yang lain, hukum tidak tertulis yang hidup dalam masyarakat, konvensi-konvensi dan perjanjian-perjanjian internasional baik bilateral maupun multilateral yang telah diratifikasi Indonesia. $^{9}$

Dari pemahaman dan pengertian di atas, harmonisasi hukum dalam tulisan ini, diartikan sebagai upaya atau proses untuk merealisasi keselarasan, kesesuaian, keserasian, kecocokan, keseimbangan, di antara normanorma hukum di dalam peraturan perundangundangan sebagai sistem hukum dalam satu

${ }^{5}$ UNIDROIT, International Institute for the Unification of Private Law, Website http://www. unidroit.org/

${ }^{8}$ M. Budiarto, Dasar-dasar Integrasi Ekonomi \& Harmonisasi Hukum Masyarakat Eropa (Jakarta: Akademika Pressindo, 1991), hlm.78.

${ }^{7}$ Jarrod Wiener, Globalization and the Harmonization of Law (New York: Pinter Imprint, 1999), hlm.1164173.

${ }^{8} \mathrm{lbid}$.

${ }^{9}$ Moh. Hasan Wargakusumah, dkk., Perumusan Harmonisasi Hukum tentang Metodologi Harmonisasi Hukum, BPHN Departemen Kehakiman, 1996/1997), hlm.37. 
kesatuan kerangka sistem hukum nasional. Dengan demikian norma-norma hukum di dalam peraturan perundang-undangan sebagai sub-sistem dalam satu kesatuan kerangka sistem hukum nasional, tidak terhalang oleh perbedaan-perbedaan, tidak saling bertentangan dan tidak terjadi duplikasi atau tumpang tindih.

\section{Harmonisasi Sistem Hukum}

Dalam harmonisasi hukum dengan pendekatan sistem yakni konotasi sistem sebagai entitas (system as an entity). ${ }^{10}$ Memandang sistem hukum nasional sebagai "suatu himpunan bagian hukum atau subsistem hukum yang saling berkaitan yang membentuk satu keseluruhan yang kompleks tetapi merupakan satu kesatuan", yang bertolok ukur pada Pancasila dan bertitik tolak pada UUD 1945 sebagai konsep dasar sistem hukum nasional.

Bertolak dari kerangka pemikiran sistem hukum, peraturan perundang-undangan sebagai suatu sistem dan komponen sistem hukum nasional, dilihat dari kerangka sistem. hukum nasional merupakan bagian atau subsistem dari sistem hukum nasional. Ketentuan hukum dalam peraturan perundangundangan sebagai suatu sistem dan subsistem hukum nasional memiliki asas yang terintegrasi dan dijiwai Pancasila serta bersumber pada UUD 1945, sehingga menjadi sistem hukum nasional yang harmonis, dalam arti selaras, serasi, seimbang dan konsisten, serta tidak berbenturan dan tidak-terdapat pertentangan di antara satu peraturan perundang-undangan dengan lainnya, baik vertikal maupun horisontal.

Dari kerangka pemikirän sistem hukum di atas, perumusan langkah ideal dalam harmonisasi sistem hukum nasional adalah upaya menyelaraskan, menyerasikan, menyesuaikan, menyeimbangkan dan konsistensi unsur-unsur sistem hukum dalam rangka mengintegrasikan berbagai sistem hukum, sehingga tersusun dalam satu tatanan yang harmonis satu sama lain dalam kerangka sistem hukum nasional. Dengan demikian, upaya harmonisasi sistem hukum nasional merupakan 'conditio sine qua non' bagi terjaminnya kepastian hukum, ketertiban hukum, penegakan hukum dan perlindungan hukum yang berintikan keadilan dan kebenaran.

\section{Perumusan Langkah Harmonisasi Sistem Hukum}

Dari dimensi ketertiban hukum (rechtsorde), sistem hukum adalah keseluruhan tertib hukum yang didukung oleh sejumlah asas. Asas sistem hukum nasional yang dijiwai Pancasila dan bersumber pada UUD 1945. Dengan demikian asas tersebut satu sama lain berfungsi sebagai pendukung hukum, menciptakan harmonisasi, keselarasan, keserasian, keseimbangan, dan mencegah kemungkinan terjadinya tumpang tindih, serta menciptakan kepastian hukum di dalam keseluruhan sistem hukum nasional. ${ }^{11}$

${ }^{10}$ William A Shrode dan Jr. Dan Voich, Organization and Management: Basic System Concepts (Malaysia: Irwin Book Co., 1974), dalam Tatang M. Amirin, Pokok-Pokok Teori Sistem (Jakarta: Raja Grafindo Persada, 2001), hlm.4-8.

11 Mariam Darus Badrulzaman, Aneka Hukum Bisnis (Bandung: Alumni, 1994), hlm.2. 
Secara konseptual kerangka sistonhukum nasional mencakup unsuri-unsur substansi hukum, struktur húkum beserta kelembagaannya dan budaya hukum. Substansi húkum merupakan aturan, norma dan pola perilaku manusia yang berada di dalam sistem atau bagaimana lembagalembaga itu berproses, yang mencakup produk yang dihasilkan oleh orang yang berada di dalam sistem tersebut, (the substance is composed of substantive rules and rules about how institutions should behave). ${ }^{12}$ Struktur hukum, ialah sistem hukum secara menyeluruh atau kerangka, bagian yang tetap bertahan yang memberi bentuk dan batasan terhadap keseluruhan atau badan institusional dari sistem yang membatasi proses, (the structure of a system is its skeletal framework; it is the permanent shape, the institutional body of the system, the tough, rigid bones that keep the process flowing within bounds), ${ }^{13}$ mencakup institusi-institusi dan aparatur penegak hukum. Budaya hukum, yaitu sebagai suasana pikiran dan kekuatan sosial yang menentukan bagaimana hukum digunakan, dihindari atau disalahgunakan (how law is used, avoided or abused), mencakup gagasan-gagasan yang dominan, kebiasaankebiasaan, cara berpikir dan cara bertindak, baik aparat penegak hukum maupun warga masyarakat; (refers, then, to those parts of general culture-customs, opinions, ways of doing and thingking that bend social forces toward or away from the law and in particular ways). ${ }^{14}$

Dengan demikian usaha harmonisasi sistem hukum nasional akan meletakkan pola pikir yang mendasari penyusunan sistem hukum dalam kerangka sistem hukum nasional (legal system harmonization) yang mencakup: (i) unsur substansi hukum (legal substance) yakni hukum yang terdiri atas tatanan hukum eksternal yaitu peraturan perundang-undangan, hukum tidak tertulis termasuk hukum adat dan yurisprudensi, serta tatanan hukum internal yaitu asas hukum yang melandasinya; (ii) unsur struktur hukum (legal structure) beserta kelembagaannya, yang terdiri atas berbagai badan institusional atau kelembagaan publik dengan para pejabatnya; dan (iii) unsur budaya hukum (legal culture), yang mencakup sikap dan perilaku para pejabat dan warga masyarakat berkenaan dengan unsur-unsur yang lain dalam proses. penyelenggaraan kehidupan bermasyarakat. ${ }^{15}$

Pemikiran sistemik harmonisasi hukum, diperlukan perumusan langkah sebagai kerangka dan konsep dasar dalam melakukan harmonisasi sistem hukum. Sebagai kerangka dan konsep dasar harmonisasi sistem hukum nasional dengan meletakkan pola pikir, yakni bermula dari paradigma Pancasila bersamasama dengan konsep negara hukum dan prinsip pemerintahan konstitusional dalam UUD $1945 .{ }^{16}$ Kemudian memperhatikan rasa

${ }^{12}$ Lawrence Meir Friedman, The Legal System, A Social Science Perspective (New York: Russell Sage Foundation, 1975), hlm.14-15.

13 lbid.

${ }^{14} \mathrm{Ibid}$.

${ }^{15}$ Lihlmat pula B. Arief Sidharta, Praktisi Hukum dan Perkembangan Hukum, dalam Wajah Hukum DiEra Reformasi(Bandung: Citra Aditya Bakti, 2000), hlm.199.

${ }^{16}$ Derivasi Sistem Pembangunan Hukum Nasional, dalam M. Solly Lubis, Sistem Nasional (Bandung: Mandar Maju, 2002), hlm.137-138. 
keadilan dan mengakomodasi aspirasi varng mendasari perumusan perencanaan hukum berkembang di dalam masyarakat.

Selanjutnya memperhatikan sistem hukum nasional sebagai masukan (input), yaitu memperhitungkan keberadaan sistem hukum nasional yang sedang berjalan (existing legal system) yang mencakup unsur-unsur: substansi hukum yakni tata hukum yang terdiri atas tatanan hukum eksternal yaitu peraturan perundang-undangan, hukum tidak tertulis termasuk hukum adat dan yurisprudensi, serta tatanan hukum internal yaitu asas hukum yang melandasinya; struktur hukum beserta kelembagaannya yang terdiri atas berbagai . badan institusional atau kelembagaan publik dengan para pejabatnya; dan budaya hukum yang mencakup sikap dan, perilaku para pejabat dan warga masyarakat berkenaan dengan unsur-unsur yang lain dalam proses penyelenggaraan kehidupan bermasyarakat.

-Seia îjutnya memperhatikan realitas keberadaan hukum nasional dan penegakannya dalam praktek pada skala nasional, regional dan global. Interaksi antara tiga komponen, yaitu: (i) paradigma Pancasila, konsep negara hukum dan prinsip pemerintahan konstitusional dalam UUD 1945 , serta rasa keadilan dan aspirasi yang berkembang di dalam masyarakat; (ii) keberadaan sistem hukum nasional mencakup unsur-unsur substansi hukum, struktur hukum beserta kelembagaannya dan budaya hukum; dan (iii) realitas keberadaan hukum nasional dan penegakannya dalam praktek pada skala nasional, regional dan global; akan menghasilkan suatu wawasan pokok-pokok pikiran hukum.

Berdasarkan wawasan dan pokok-pokok pikiran hukum tersebut akan melahirkan konsep harmonisasi sistem hukum, yang akan (I0)isiation planning) dan proses pembentukan hukum (law making process) meiaiưi pẹeraiuiran neründang-undangan. Pada akhirnya melalui penerapan tuk kum (law enforcement) diharapkan akan tercipta pergturan perundang-undangan nasional yang harmonis, dalam arti selaras, serasi, seimbang, terintegrasi dan konsisten serta taat asas, sebagai keluaran (output) produk dari proses harmonisasi hukum.

Penilaian atau evaluasi terhadap hasil yang dicapai yakni produk harmonisasi hukum tersebut, baik yang berkaitan dengan pengaruhnya terhadap keberadaan sistem hukum nasional yang sedang berjalan yang mencakup unsur-unsur substansi hukum, struktur hukum beserta kelembagaannya dan budaya hukum, selanjutnya akan menimbulkan suatu wawasan hukum baru yang akan memperbarui pula wawasan dan perumusan garis kebijakan hukum ke depan. Dalam kerangka sistemik demikian secara berkelanjutan, harmonisasi hukum akan terusmenerus berkembang di dalam satu kerangka sistem hukum nasional dengan pendekatan sistem dan pandangan konseptual.

Perumusan konsep langkah sistemik harmonisasi hukum, sebagai konsep dasar dan kerangka umum yang memberikan pedoman dalam penyesuaian asas dan sistem hukum pada proses pembentukan peraturan perundang-undangan, dalam rangka mewujudkan peraturan perundang-undangan nasional yang harmonis, terintegrasi, konsisten dan taat asas.

\section{Harmonisasi Sistem Hukum Nasional}

Untuk mewujudkan sistem hukum 
nasional, secara ideal dilakukan pembinaan yang terarah sejak tahap perencanaan hyukum, pembentukan hukum; penerapan :dan penegakannya, sehingga semua komponen sistem hukum nasional terangkai dalam suatu tatanan yang teratur dan berhubungan satu sama lain secara harmonis dalam satu kesatuan yang utuh. Dengan memperhatikan 'principles of legality' yang, dipersyaratkan Fuller, ${ }^{17}$ pembentukan undang-undang sebagai instrumen utama sistem. hukum nasional, mengenai segi substansi dalam pembentukan undang-undang dihadapkan pada berbagai kompleksitas. Di antaranya keterkaitan pengaturan berbagai bidang yang semakin kompleks dan adanya pengaruh giobal, serta sistem hukum Anglo-American (common law system) yang mempengaruhi kehidupan hukum di Indonesia. Semua harus diperhatikan, dipertimbangkan dan diharmonisasikan-dalam pembentukan undang-undang.

Peraturan perundang-undangan yang dibentuk melalui suatu proses harmonisasi sosial akan memperoleh kepercayaan dari masyarakat, sebagai yang menjanjikan akan memberikan ketertiban dan keadilan kepada kehidupan bermasyarakat. Konsekuensinya peraturan perundang-undangan harus mengandung nilai filosofis, nilai sosiologis dan nilai yuridis. Artinya, peraturan perundangundangan itu-memenuhi nilai filosofis yang berintikan rasa keadilan dan kebenaran, nilai sosiologis yang sesuai dengan tata nilai budaya yang berlaku di dalam masyarakat dan nilai yuridis yang sesuai dengan ketentuan peraturan perundanig-undangan yang berlaku. Nilai filosofis, nilai sosiologis dan-nilai yuridis, hanya dapat terwujud. apabila pembentukan pẹraturan perundang undangan mampu mewujựakan keserasian, keselärasan dăn kèseimbangan, serta memperilihatkan suatu alựr könsistensi dan taat asas. Pembentukan peraturan perundang-undangan yang tidak konsisten dan taat aśas, tidak akañ menjadikan masyárákat maư mengandalkannya sebagai perangkat norma yăng mèngatur hidup bermasyarakat. ${ }^{18}$ Konsistensi dan ketaatan asas "dálam penyelenggàraan hukum demikiân ini yang dapat disebut sébagai kepastian hukum.

Séhubungan dengan hal tersebut, untuk menjamin terbentuknya peratưarn perundangundangan yang baik, ântara lain mengandung moralitas teitentu, mengandung keharmonisan, tidak terhalang oleh perbedaan-perbedaan, tidak saling bertentangan; terikàt dalam sistem, berisid dan tahan wáktu lama, dipếrlukan proses harmonisasi hukum. Hämonisasi hukum sebagai suatu proses dalam pembentukan peiaturan perundang-undangan, mengatasi batasan perbedaan, hall-hal yang bertentangan dan kejánggalán, di ăntara norma-norma hukum dalam peraturan perundang-undangan sebagai sub-sistem dalam kerangka sistem hukum ñasional. Dengan demikian akan terbentuk peraturan perundäng-undangan nasional yang harmonis, dalam arti selaras, șerasi, șeimbang, terintegrasi dan konsisten serta taat asas.

${ }^{17}$ Lon L. Fuller, "The Morality of Law," dalam M.D.A. Freeman, introduction to Jurisprudence, Fifth edition (London: Stevens \& Sons Ltd., 1985), hlm.187.: " :

${ }^{18}$ Lihat Budiono Kusumohamidjojo, op.cit:; hlm.150. 
Harmonisasi Sistem Hukum Internasional

Dalam menghadapi era globalisasi, sangat mendesak bagi Indonesia untuk melakukan harmonisasi dalam perencanaan dan pembentukan hukum nasional yang sesuai dengan kecenderungan internasional. Langkah yuridis antisipatif dalam menghadapi globalisasi perdagangan, secara substansial dilakukan persiapan untuk melakukan harmonisasi hukum yang cepat dan terencana antara peraturan perundang-undangan nasional dengan instrumen-instrumen regional dan internasional.

Setiap negara merdeka memiliki sistem hukum nasionalnya sendiri, sehingga ragam sistem hukum sebanyak negara-negara merdeka yang ada di dunia. Perbedaan sistem hukum tersebut, dalam pergaulan internasional dan dalam hubungan perdagangan antar negara era global yang mendorong liberalisasi ekonomi dan kompetisi pasar bebas, akan melahirkan akibat-akibat terhadap ketertiban hukum, perlindungan hukum dan kepastian hukum. Dalam kaitan inilah harmonisasi sistem hukum menjadi sebuah keniscayaan,' agar tetap dalam ketertiban hukum, jaminan perlindungan hukum dan kepastian hukum.

Langkah harmonisasi sistem hukum, melakukan tindakan pengharmonisan atau penyesuaian yang harmonis sistem hukum tertentu, menjadi sistem hukum yang bersifat global yang dapat diakui dan diterima oleh berbagai negara dalam melaksanakan tarnsaksi-transaksi perdagangan internasional. Dalam penggunaan model-model hukum asing 'uniform laws' dan 'model laws' baik penggunaan itu dalam bentuknya semula (adoption), maupun dalam bentuk yang sudah diubah (adaptation), diperlukan acuan dasar mengenai hukum-hukum internasional yang dapat mengakomodasi kebutuhan hukum nasional, sehingga tercipta peraturan perundang-undangan nasional yang harmonis dan dalam alur taat asas.

Dengan demikian yang dimaksud dengan harmonisasi sistem hukum internasional, ialah pengharmonisan pluralitas sistem hukum dalam sistem hukum intemasional untuk membentuk uniformitas sistem hukum yang dapat disetujui dan diterima oleh semua negara dalam melaksanakan transaksi-transaksi perdagangan internasional. Dirumuskan dalam dua langkah, yaitu penyesuaian sistem hukum nasional menjadi sistem hukum yang bersifat global, dan dengan demikian yang harmonis dan seragam hukum positifnya (harmony of law); dan penyesuaian norma-norma hukum tertentu menjadi satu kesatuan norma yang bersifat global, yang dapat digunakan sebagai sarana penyelesaian sengketa, dan dengan demikian yang harmonis dan seragam, keputusan-keputusan hakim (harmony of decision) secara global.

\section{Kewenangan Badan Khusus Terkait Kewenangan Badan Peradilan}

Dalam kaitannya dengan aspek hukum piutang, badan khusus diberikan kewenangan untuk melakukan penagihan kepada debitur dengan menerbitkan surat paksa. Dalam keadaan demikian, badan khusus berkedudukan sebagai eksekutor tanpa melalui proses peradilan dan pihak tereksekusi tidak memiliki hak untuk menempuh upaya hukum. Badan khusus bukan lembaga peradilan tetapi putusannya disamakan dengan putusan lembaga peradilan yang bersifat serta merta 
(uitvoerbaar bij voorraad). Dari segi perlindungan hukum, tidak terdapat ketentuan yang memberikan kesempatan bagi para pihak untuk menempuh upaya hukum terhadap keputusan badan khusus, sedangkan kedudukan badan khusus sebagai lembaga bersifat sementara, maka dapat dikatakan sebagai kewenangan yang melanggar sistem hukum yang dibangun melalui UU No.14 Tahun 1970, jo. UU No.35 Tahun 1999, seperti digantikan UU No.4 Tahun 2004, tentang Kekuasaan Kehakiman.

Dari segi ilmu hukum, surat paksa yang diterbitkan oleh badan khusus yang diberi kekuatan eksekutorial tidak menjadikan surat paksa tersebut kemudian identik dengan suatu putusan hakim yang telah mempunyai kekuatan hukum tetap (inkracht van gewisjde), yang merupakan hasil pemeriksaan badan peradilan melalui proses seperti ditentukan dalam hukum acara perdata yang diatur dalam HIR dan RBg. Bukan pula merupakan hasil pemeriksaan badan peradilan tata usaha negara melalui proses seperti ditentukan dalam hukum acara peradilan administrasi seperti ditentukan dalam UU No.5 Tahun 1986, tentang Peradilan Tata Usaha Negara, diubah dengan UU No.9 Tahun 2004.

Surat paksa yang diterbitkan badan khusus semacam itu lebih dapat dikategorikan sebagai suatu keputusan tertulis tata usaha negara (beschikking) yang bersifat konkret, individual dan final, seperti dimaksud dalam Pasal 1 angka 3 UU No.5 Tahun 1986, jo. UU No.9 Tahun 2004, sehingga dapat digugat melalui Pengadilan Tata Usaha Negara untuk pembatalannya. Di samping itu, bagi pihakpihak yang merasa dirugikan akibat diterbitkannya surat paksa oleh badan khusus, masih dapat menggugat melaiui Pengadilan
Negeri atas dasar perbuatan melawan hukum (onrechtmatige daad) eks Pasal 1365 BW, untuk menuntut ganti kerugian.

\section{Pergeseran Konsep Hukum}

Untuk memperoleh dasar pembenaran diberikannya kewenangan kepada badan khusus menerbitkan surat paksa dan peletakan sita eksekusi di atas, dengan asumsi dasar pembenaran untuk memulihkan kondisi perbankan serta mengembalikan uang negara yang telah tersalur di sektor perbankan. Dasar pembenaran demikian didasarkan pada pemikiran bahwa penyelesaian melalui pengadilan dianggap akan memakañ waktu lama dan tidak menjamin kepastian untuk mengembalikan uang negara yang telah tersalur di sektor perbankan. Apabila asumsi ini benar, maka. pemahaman dasar pembenaran demikian terlihat sebagai alasan yang tidak didasarkan pada hukum.

Alasan pembenar demikian merupakan suatu upaya dalam mencari alasan dasar pembenar bagi suatu konstruksi hukum yang tidak benar. Dengan jalan 'paksaan' seperti ditentukan dalam Pasal 37A ayat (3) huruf $i$. UU No.10 Tahun 1998 yang dilakukan oleh badan khusus tersebut, merupakan pembenaran terhadap suatu tindakan yang menurut sistem hukum tidak dibolehkan. Badan khusus yang semula menggantikan kedudukan bank sebagai kreditur, kemudian dapat dikatakan bertindak 'main hakim sendiri' (eigenrichting) yang merupakan bentuk kesewenang-wenangan (naar willekeur handelen). Keadaan demikian telah menyangkut pergeseran konsep hukum, yaitu konsep yang bersifat hukum keperdataan (privaatrechttelijk) bergeser menjadi konsep 
yang bersifat hukum publik (publiekrechttelijk).

Dalam keadaan demikian, menjadi sangat penting untuk dilakukan harmonisasi hukum agar dapat selalu taat pada asas hukum. Melalui harmonisasi hukum akan tercipta keharmonisan, keserasian, keseimbangan dan ketaatan asas, serta keterpaduan hukum dalam kerangka sistem hukum nasional sebagai instrumen untuk menciptakan kebenaran, keadilan dan kedamaian dalam kehidupan masyarakat.

\section{Harmonisasi Kewenangan Penagihan Uang Negara}

Dalam kerangka pembangunan perekonomiari nasional, kebijakan-kebijakan sektor keuangan khususnya sektor perbankan akan berpengaruh secara langsung terhadap iklim dan arah pembangunan perekonomian nasional. Berkaitan hal itu, pengembalian uang negara yang telah tersalur di sektor perbankan dapat menimbulkan implikasi yang membahayakan keuangan negara. Kriteria keuangan negara menjadi penting di dalam setiap penanganan piutang negara, sebab akan menentukan bentuk-atau pola mana yang tepat untuk pengurusannya. Di samping itu pentingnya pengertian keuangan negara, untuk membedakan uang negara yang telah tersalur di sektor perbankan yang disebut sebagai piutang negara.

Kewenangan melakukan tindakan hukum yang diberikan badan khusus dalam melakukan penagihan uang negara yang telah tersalur $\mathrm{di}$ sektor perbankan, dapat dikategorikan ke dalam bentuk-bentuk berikut: (i) tindakan hukum yang mempunyai lingkup pada aspek penagihan (collecting activities) tanpa memperhatikan kelayakan usaha debitur atau penanggung utang; (ii) tindakan hukum yang mempunyai lingkup pada aspek restrukturisasi (restructuring activities) dengan memperhatikan aspek kelayakan dan prospek usaha debitur atau penanggung utang; (iii) tindakan hukum yang bersifat campuran (mixing activities) antara collecting activities dan restructuring activities, yang dapat berakhir dengan merger atau likuidasi; (iv) tindakan hukum yang bersifat penyelesaian Aset Dalam Restrukturisasi dan Kredit Dalam Restrukturisasi, yang dilakukan secara khusus dengan memberikan tindakan--tindakan yang bersifat perdamaian (amicable settlement), yang berakhir dengan diterbitkannya Release and Discharge (jaminan pembebasan dari proses dan tuntutan hukum); (v) tindakan hukum melalui proses pengadilan yang diajukan atas inisiatif salah satu pihak, memberikan putusan yang bersifat judicial settlement.

Kewenangan melakukan tindakan hukum yang diberikan badan khusus dalam melakukan penagihan uang negara di atas, telah terjadi tumpang tindih dan mengesampingkan kewenangan badan peradilan khususnya kekuasaan lingkungan peradilan umum. Mengesampingkan kewenangan badan peradilan, dapat berarti pengesampingan terhadap kekuasaan badan peradilan yang merdeka dalam menyelenggarakan peradilan guna menegakkan hukum dan keadilan, seperti dikehendaki Pasal 24 UUD 1945.

Kekuasaan badan peradilan yang merdeka, menjadi bagian dari ajaran tentang paham konstitusi (konstitualisme) di mana setiap kekuasaan harus tunduk pada hukum dan perlindungan terhadap rakyat, maka mengesampingkan kekuasaan badan peradilan yang merdeka merupakan pengingkaran terhadap konstitualisme. Dengan demikian dalam penyelenggaraan 
pemerintahan, kewenangan badan khusus berkenaan pelaksanaan fungsi penyehatan perbankan nasional yang ditentukan dalam Pasal 37AUU. No.10 Tahun 1998 tersebut tidak hanya telah terjadi tumpang tindih kewenangan, melainkan juga kewenangan yang mengingkari asas negara berkonstitusi yakni asas demokrasi dan asas negara hukum.

Dalam keadaan demikian, akan lebih bijaksana kalau kewenangan badan khusus berkenaan dengan fungsi penyehatan perbankan, yang ditentukan dalam Pasal 37A UU No.10 Tahun 1998 diharmonisasikan dalam rangka mewujudkan sistem hukum nasional yang harmonis. Harmonisasi peraturan perudang--undangan yang secara substansial menentukan aturan koordinasi dan sinkronisasi di antara badan-badan negara yang melakukan penagihan uang negara. Dengan harmonisasi demikian diharapkan dapat terwujud suatu standar model penagihan uang negara.

Harmonisasi dalam bentuk sinkronisasi dan koordinasi tersebut menjadi sangat penting di antara badan-badan yang melakukan penagihan uang negara, agar kebi-jakan dalam penagihan uang negara menjadi konsis-ten dan terarah serta tidak tumpang tindih, sekaligus mengeliminir sikap moral hazard baik di antara para kreditur, debitur atau penanggung utang serta otoritas penge-lola piutang negara. Koordinasi dimaksudkan adanya kerjasama yang baik dalam penagihan uang negara yang meliputi penyelesaian utang piutang antara debitur dan kreditur. Sinkronisasi dimaksudkan adanya penyelesaian Aset Dalam Restrukturisasi dan Kredit Dalam Restrukturisasi yang secara ideal berada pada satu otoritas penge-lola piutang negara dan dalam kaitannya dengan penyelesaian sengketa melalui lembaga peradilan.

\section{Harmonisasi Hukum Perbankan dan Hukum Perekonomian Nasional}

Secara konseptual dikemukakan John Henry Merryman, tiga kerangka model reformasi hukum yang disebut sebagai model reformasi hukum, "law reform: tinkering, following dan leading". ${ }^{19}$ Dalam hal model reformasi hukum yang dikemukakan Merryman diterapkan sebagai kerangka model pada harmonisasi hukum, maka secara teoritik akan dikenal tiga model harmonisasi hukum, yaitu tinkering harmonization', "following harmonization' dan 'leading harmonization'. Dalam pengertian, kerangka model harmonisasi hukum yang diderivasi secara langsung dari model reformasi hukum tinkering', 'following' dan 'leading'.

Dengan demikian di dalam harmonisasi hukum, yang dimaksud dengan tinkering harmonization' merupakan harmonisasi hukum

19 John Henry Merryman, "Comparative Law and Social ChImange: On the Origins, Style, Decline \& Revival of the Law and development Movement," The American Journal of Comparative Law, Vol.25, 1977, http//:www.imf.org/external/pubs/ft/seminar/1999/reforms/trebil.pdf; Lihat pula J. Faundez, "Legal Reform In Developing and Transition Countries Making Haste Slowly, "University of Warwick, http://www.worldbank.org/ legal//egop_judicial//ir_conf_papers/faundez.pdf/harmonization+law\#1; lihat pula Nandang Sutrisno, "Impor Hukum Ekonomi sebagai Strategi Antisipatif Menghadapi Era Pasar Bebas," Jurnal Hukum Ekonomi, EdisiV, LPHE, 1996, him.47-48. 
melalui optimalisasi penerapan hukum yang ada (existing law) dengan beberapa penyesuaian. 'Following harmonization', menunjuk pada harmonisasi hukum bidangbidang tertentu yang ditujukan untuk penyesuaian hukum yang ada dengan perubahan-perubahan. Leading harmonization', menunjuk pada penerapan atau penggunaan hukum untuk melakukan perubahan-perubahan.

Dalam kerangka model dikemukakan di atas, produk hukum yang tercipta dari pengambilan langkah tinkering harmonization' atau 'following harmonization' dalam melakukan harmonisasi hukum di bidang perbankan dan keuangan serta perekonomian dalam era globalisasi akan mudah tertinggal perubahan-perubahan keadaan. Dengan kata lain, produk hukum yang dihasilkan cenderung akan cepat diubah-sehingga kurang memenuhi 'prinsiples of legality' seperti yang dipersyaratkan Fuller, karena "introducing such frequent changes in the rules that the subject cannot orient his action by them". ${ }^{20}$ Dengan demikian secara ideal ditempuh langkah harmonisasi hukum yang-bersifat leading harmonization'. Produk hukum yang tercipta dalam harmonisasi hukum yang bersifat "leading harmonization', akan lebih antisipatif terhadap liberalisasi perbankan dan perdagangan serta perekonomian di masa yang datang. ${ }^{21}$

Langkah harmonisasi hukum yang bersifat 'leading harmonization', dengan menjadikan sebagai model baik dalam bentuknya semula (adoption) ataupun dalam bentuk yang sudah diubah (adaptation), modelmodel hukum perbankan dan hukum keuangan serta hukum ekonomi negaranegara maju, yaitu 'uniform laws' dan 'model laws' hasil perancangan badan-badan internasional, seperti BIS, IBRD, ICC, WTO, UNCTAD, ICSID, UNCITRAL, UNIDROIT, dan konvensi-konvensi internasional lainnya. ${ }^{22}$ Dengan menempuh langkah harmonisasi hukum demikian, norma-norma hukum yang dihasilkan lebih mempunyai nilai-nilai yang bersifat transnasional.

Dalam mencapai suatu perbankan yang sehat, kuat dan efisien, guna mewujudkan stabilitas sistem keuangan serta mendorong pembangunan ekonomi nasional, harmonisasi sistem hukum perbankan nasional merupakan suatu pilihan yang penting untuk dilakukan. Dalam rangka harmonisasi sistem hukum perbankan, secara ideal dibentuk undang-undang tentang penyelesaian bank bermasalah untuk mengatasi masalah-masalah yang dialami perbankan nasional yang meliputi 'banking distress' dan 'banking crisis'. Pembentukan undang-undang tentang penyelesaian bank bermasalah secara substansial mengatur pemecahan masalah utang-piutang antara debitur dan kreditur, meliputi restrukturisasi sektor perbankan dan retsrukturisasi utang perusahaan, yang konsisten dalam kerangka sistem hukum nasional.

${ }^{20}$ Lon L. Fuller, op.cit.

${ }^{21}$ Lihat pula Nandang Sutrisno, op.cit.

${ }^{22}$ Lihat, Sia Aik Kor, Regional Efforts and Cooperation on Legal and Judicial Reform, http:// www4.worddbank.org/legal/asean.pdf/harmonization+law 


\section{Simpulan}

Langkah sistemik harmonisasi hukum nasional bertumpu pada paradigma Pancasila dan UUD 1945 yang melahirkan sistem ketatanegaraan dengan dua asas fundamental, asas demokrasi dan asas negara hukum yang diidealkan mewujudkan sistem hukum nasional dengan tiga komponen, yaitu substansi hukum, struktur hukum beserta kelembagaannya dan budaya hukum. Langkah sistemik tersebut di satu sisi dapat dijabarkan dalam harmonisasi peraturan perundang-undangan dan di sisi lain dimplementasikan dalam rangka penegakan hukum.

Melalui harmonisasi peraturan perundang-undangan akan terbentuk sistem hukum yang mengakomodir tuntutan akan kepastian hukum dan terwujudnya keadilan. Begitu pula dalam hal penegakan hukum, harmonisasi hukum akan dapat menghindari tumpang tindih bagi badan peradilan yang melakukan kekuasaan kehakiman dengan badan-badan pemerintah yang diberi wewenang melakukan fụngsi peradilan menurut peraturan perundang-undangan.

Kewenangan badan khusus yang ditentukan dalam Pasal 37A UU No.10 Tahun 1998, merupakan kewenangan yang mengingkari asas negara berkonstitusi yakni asas demokrasi dan asas negara hukum. Wewenang badan khusus dalam menjalankan fungsi penyehatan perbankan nasional, melanggar batas eksternal institusional kekuasaan badan peradilan umum di lingkungan kekuasaan kehakiman khususnya peradilan perdata.
Dalam rangka harmonisasi peraturan perundang-undangan bidang perbankan, secara ideal dibentuk undang-undang tentang penyelesaian bank bermasalah, yang secara substansial mengatur pemecahan masalah utang-piutang antara debitur dan kreditur, meliputi restrukturisasi sektor perbankan dan retsrukturisasi utang perusahaan, yang konsisten dalam kerangka sistem hukum nasional.

Dalam hal timbul kejanggalan dan pertentangan di antara norma hukum yang diatur di dalam peraturan perundangundangan dalam kerangka sistem hukum nasional, pemecahan masalahnya melalui harmonisasi hukum. Dasar dan orientasi dalam setiap langkah harmonisasi hukum adalah tujuan harmonisasi, nilai-nilai dan asas hukum, serta tujuan hukum itu sendiri, yaitu harmoni antara keadilan, kepastian hukum dan sesuai tujuan (doelmatigheid).

\section{Daftar Pustaka}

Amirin, Tatang M., Pokok-Pokok Teori Sistem, Jakarta: Raja Grafindo Persada, 2001.

Badrulzaman, Mariam Darus, Aneka Hukum Bisnis, Bandung: Alumni, 1994.

Budiarto, M., Dasar-dasar Integrasi Ekonomi \& Harmonisasi Hukum Masyarakat Eropa, Jakarta: Akademika Pressindo, 1991.

Chand, Hari, Modern Jurisprudence, Kuala Lumpur: International Law Book Services, 1994.

Faundez, J., Legal Reform In Developing and Transition Countries Making Haste Slowly', University of Warwick, http:ll 
www. worldbank.org/legall legop judicial/lir cont papers/ faundez.pdt/harmonization

Freeman, M.D.A., Introduction to Jurisprudence, London: Stevens \& Sons Ltd, 1985.

Friedman, Lawrence Meir, The Legal System, A Social Science Perspective, New York: Russell Sage Foundation, 1975.

Huijbers, Theo, Filsafat Hukum Dalam Lintasan Sejarah, Yogyakarta: Kanisius, 1982.

-Kor, Sia Aik, 'Regional Efforts and Cooperation on Legal and Judicial Reform', A World Bank Conference, Co-Hosted by the Government Russia, http:l/ www4.worldbank.org/legal/asean.pdf' harmonization, 1999.

Kusumohamidjojo, Budiono, Ketertiban Yang Adil, Problematik Filsafat Hukum, Jakarta: Grasindo, 1999.

Lubis, M. Solly, Sistem Nasional, Bandung: Mandar Maju, 2002.

Merryman, John Henry, 'Comparative Law and Social Change: On the Origins, Style, Decline \& Revival of the Law and development Movement', The American
Journal of Comparative Law, V.25, http/ ':www.imf.org/external/pubs/tt/seminar/ 1999/reforms/

Rawls, John, A Theory of Justice, Oxford, New York: Oxford University Press, 1973.

Sidharta, B. Arief, Praktisi Hukum Dan Perkembangan Hukum, dalam Wajah Hukum Di Era Reformasi, Bandung: Citra Aditya Bakti, 2000.

Sutrisno, Nandang, Impor Hukum Ekonomi Sebagai Strategi Antisipatif Menghadapi Era Pasar Bebas, Jurnal Hukum Ekonomi, Edisi V: 47-48, 1996.

UNCITRAL, The United Nation Commission on International Trade Law, Website http:// www.uncitral.org/

UNIDROIT, International Institute for the Unification of Private Law, Website http:/l www.unidroit.org/

Wargakusumah, Moh. Hasan, dkk., Perumusan Harmonisasi Hukum Tentang Metodologi Harmonisasi Hukum, BPHN Departemen Kehakiman, 1996/1997.

Wiener, Jarrod, Globalization and the Harmonization of Law, New York: Pinter a Cassell Imprint, 1999. 